\title{
From conflicts to wise practice agreement and national strategy: cooperative learning and coastal stewardship in estuarine floodplain management, Tweed River, eastern Australia
}

\author{
Ian White ${ }^{\mathrm{a}, *}$, Mike Melville ${ }^{\mathrm{b}}$, Ben Macdonald ${ }^{\mathrm{a}}$, Robert Quirk ${ }^{\mathrm{c}}$, Robert Hawken ${ }^{\mathrm{c}}$, \\ Mark Tunks ${ }^{\mathrm{d}}$, Don Buckley ${ }^{\mathrm{d}}$, Rick Beattie ${ }^{\mathrm{e}}$, John Williams ${ }^{\mathrm{f}}$, Lance Heath ${ }^{\mathrm{a}}$ \\ ${ }^{a}$ Centre for Resource and Environmental Studies, Australian National University, Canberra, ACT 0200, Australia \\ ${ }^{\mathrm{b}}$ School of Biological, Earth and Environmental Sciences, University of NSW, NSW 2057, Australia \\ ${ }^{\mathrm{c}}$ NSW Canegrowers Association, Condong Sugar Mill, Condong, NSW 2484, Australia \\ ${ }^{\mathrm{d}}$ Tweed Shire Council, PO Box 816, Murwillumbah, NSW 2482, Australia \\ ${ }^{\mathrm{e}}$ NSW Sugar Milling Co-operative Limited, 117 Pacific Highway, Broadwater, NSW 2472, Australia \\ ${ }^{\mathrm{f}}$ NSW Agriculture, Wollongbar Research Centre, Wollongbar, NSW 2466, Australia
}

Received 23 December 2004; accepted 31 July 2006

Available online 13 October 2006

\begin{abstract}
Appropriate information, participatory processes and wise practice agreements are key elements in reducing conflicts over the use and management of coastal resources. In this work we describe the evolution of a cooperative learning approach to coastal floodplain management, incorporating these elements. Government-encouraged drainage of coastal floodplains in eastern Australia caused accelerated oxidation of acid sulfate soils and export of diffuse acidic drainage into streams. Major impacts on infrastructure, ecology, fisheries and aquaculture resulted. In the Tweed River estuary, in 1987, all gilled organisms were killed by acid discharge from floodplain canelands. This generated major conflicts between fishers, environmentalists and sugarcane producers. The cooperative learning partnership that evolved, involving cane farmers, local government, and researchers, has produced better strategies for managing sulfidic estuarine areas and mitigating impacts on downstream ecosystems. These underpinned mandatory best practice management guidelines for the NSW sugar industry. Increases in productivity and decreases in acid discharge have resulted. Fish kills on the Tweed and elsewhere also generated broader, parallel whole-of-government approaches that led to Australia's national strategy for managing coastal acid sulfate soils and the rapid adoption of information and strategies across Australia.

(C) 2006 Elsevier Ltd. All rights reserved.
\end{abstract}

Keywords: Coastal floodplain management; Acid sulfate soils; Cooperative learning; Wise practice agreements; Acidic discharge; Diffuse source pollution

\section{Introduction}

\subsection{Global challenges of coastal zone management}

The annual value of the world's coastal goods and ecosystem services has been estimated to be about US\$24 trillion, compared with a global gross domestic product of around US\$18

\footnotetext{
* Corresponding author. Tel.: +61 26125 0660; fax: +61 261250757. E-mail address: ian.white@anu.edu.au (I. White).
}

trillion [1]. While the former figure is questionable, coastal ecosystems are both immensely valuable and valued by communities. Coastal regions and estuaries are distinctive because they involve so many different sectors of society that claim right of access and use of resources. This often results in lengthy, expensive and counterproductive conflicts [2].

Despite their importance, coastal areas continue to degrade through both natural and human-induced changes [3]. Of the human pressures, cropping and grazing and mega cities in coastal catchments have the largest impacts [4]. Increased diffuse source discharges of nitrogen, carbon and sediment, as 
a result of changes in coastal land and water regimes, are major concerns [5]. Studies of nutrient processes in near shore areas suggest that population density and percentage of land under crops in coastal catchments provide useful proxy measures of coastal disturbance [6]. Trigger values for identifying regions of highly disturbed coastal catchments have been set at densities as low as 60 persons $/ \mathrm{km}^{2}$ and $10 \%$ of catchment cleared [3,6].

Although examples of localised coastal improvement exist, sustainable resource use and maintaining coastal systems functions remain vital global tasks. Some of the key challenges include [5]: improving the availability and accessibility of resource and environmental information; fostering participatory approaches to coastal zone management; developing wise use options and agreements (best management practices); ensuring that planning and management cope with change; and developing policies that take into account risks and vulnerability.

\subsection{Information, participation and coastal stewardship}

Some, concerned by continued environmental degradation, believe that it is not possible to wait while the knowledge gaps in complex, coastal ecosystems are researched. Instead, action learning or adaptive management has been proposed as a practical response to the difficulties of managing complex situations $[7,8]$. It is argued that, in an adaptive process, mistakes due to incorrect information can be easily identified through rigorous monitoring and be corrected. Adaptive management, however, assumes linear processes where the consequences of erroneous actions can be reversed readily. Systems such as estuaries, however, appear to behave in a non-linear, hysteretic manner, exhibiting dramatic collapses that are not easily reversed [9].

Information on coastal ecosystem functions is patchy, even in intensively managed areas [10]. The general paucity of data is also evident in Australia. Relatively little research has been undertaken on the processes, consequences of environmental change or impacts of human activities in coastal eastern Australia, despite the concentration of population there [11]. The psychology of change management suggests change is more readily embraced when the underlying reasons for change are understood [12]. Appropriate, reliable information, communicated in a relevant way, is an important catalyst for change. The challenge is to collect and transmit that information in ways that are trusted by conflicting sectors.

Experience indicates that the first step in resolving conflict is to describe its nature and cause [2]. The next step is identifying and bringing together all stakeholders in a participatory manner, to try and build consensus and reach compromise agreements [13]. To reach agreement, there needs to be a process or mechanism in which the conflicting parties have confidence, and where they are able to address and resolve conflicts. Independent, impartial, outside parties, such as universities have been found to be very useful in developing higher quality agreements [2]. Problems in the management of coastal resources in eastern Australia have flowed from the plethora of top-down, conflicting visions and disparate goals between protection, rehabilitation, economic development and regional employment growth, as well as the inheritance of past legislation and administrative goals [11]. Governments are frequently reluctant to embark on participatory processes, as they are very time-consuming, and often use them as a last resort in solving conflicts.

Coastal stewardship has been proposed as one way of reducing conflicts by promoting ownership and pride in a country's heritage. It involves voluntary compliance, strong commitment and willing participation in the sustainable use of coastal resources and the development of wise practices [14]. The challenges in coastal stewardship are to inform, educate, motivate and empower communities to become managers and custodians of their environment. There are concerns, however, that without strong underpinning regulations, voluntary compliance agreements contain no effective mechanisms to address persistent breaches.

In this paper we examine the use of information, participation, and coastal stewardship in resolving serious conflicts over coastal floodplain management, stemming from fish kills, and in developing wise practice agreements for coastal floodplains in eastern Australia. We describe a cooperative learning partnership that has evolved over the last 15 years, which included local government, cane farmers and their industry, and academic institutions. This approach has successfully addressed some of the important challenges outlined above. We also describe the parallel institutional changes at the State level that flowed from the fish kills and eventually led to the production of a national strategy for the management of coastal acid sulfate soils and the rapid adoption of information and strategies across Australia. We first outline issues concerned with coastal zone development in Australia.

\section{Coastal zone development in eastern Australia}

About $80 \%$ of Australians live in the coastal zone, and about $66 \%$ of these are concentrated around large urban centres on estuaries and inlets. In the period 1971 to 1991 the population of the non-metropolitan coastal zone grew by $95 \%$, from 2.1 to 4.1 million people, compared with a $32 \%$ growth for all of Australia. About $25-30 \%$ of the coast is subject to increasing development, most of this concentrated in the south eastern section of the country. In South Australia, more than half the land is cleared in $86 \%$ of estuaries. In Victoria the figure is $60 \%$ and in New South Wales 37\% [15].

There are clear indications that coastal developments are changing the coastal, estuarine and marine ecology. For example, the dramatic decline in Australia's seagrass beds, up to $85 \%$ in some areas, due to nutrient outputs in the south east and sediment loads in the north east, is but one indicator of land-based impacts [15]. Given their fundamental importance in the marine food chain, disappearing seagrasses and their slow rate of recovery are major concerns.

\subsection{Floodplain development}

Eastern coastal floodplains in Australia were the first areas developed for agriculture following European settlement, due to their favourable temperatures, plentiful soil water and young, fertile soils [16]. Their plentiful soil water was associated with 
large expanses of wetlands and low-lying areas with high water tables. While coastal floodplains were valuable refuges for cattle grazing during droughts, waterlogging was a major constraint to both cropping and improved pastures. Governments therefore encouraged land drainage to improve production. Landholder-initiated drainage in the eastern Australian state of New South Wales (NSW) dates back to the 1820s. The attendant, increased investments in floodplain agriculture, however, required protection from frequent floods and storm surges. This protection usually involved re-engineering the floodplain [11].

As a result of the re-engineering, the time scale for inundation of many backswamp areas has been reduced from of order 100 days to around 5 days [17]. As a consequence, most drained floodplains are, on average drier, and export drainage waters at a much greater rate through more efficient reengineered drainage paths. This increase in rate of drainage discharge with its accompanying sediment and chemical loads is particularly important as it can exceed the natural assimilation capacity of receiving waters. Naturally occurring, periodic, severe droughts linked to the El Niño-Southern Oscillation and Pacific Decadal Oscillation also dried out coastal floodplains in eastern Australia before agricultural development [18]. However the natural, meandering vegetation and debris-encroached drainage channels were much less efficient at delivering subsequent runoff to receiving waters [19].

\subsection{Institutional responsibilities for floodplain management and drainage}

In order to understand floodplain drainage and management in eastern Australia and how changes to them occurred, it is necessary to appreciate the spectrum of institutional responsibilities that prevailed. There are three tiers of elected government in the Australian federation, the Commonwealth, State (and Territory) and local governments. The Commonwealth by constitution has powers over defence, trade between States and has carriage of international agreements. Natural resources ownership, and their planning and management are invested in the State and Territory governments by the Australian Constitution. Local governments are the principal means for communities to express their identity, enhance their well-being, care for their environments and relate to State and Commonwealth governments. In some states, responsibility for certain natural resources, such as the delivery of water, has been devolved to local governments. The various government agencies and authorities often have conflicting responsibilities for the coastal areas so that, ultimately, no specific agency or institution is responsible for their management [20,21]. In an attempt to address this, some States have devolved certain natural resource management functions at the catchment scale to Catchment Management Authorities, statutory authorities run by ministerially appointed boards, who are charged with developing and implementing land and water resource management plans.

Frequent floods in eastern Australia's coastal NSW, particularly in the 1950s, led to the development of joint Australian Commonwealth-NSW State government flood mitigation schemes. These schemes required participation from local governments and led to the construction of levees, floodgates, retention basins and major primary canals on some of the coastal river system in NSW. Responsibility for these major schemes has now been devolved to local governments.

The now superseded NSW Drainage Act of 1904 established Drainage Unions to manage large secondary tributary drains feeding into main drains or directly into coastal rivers. These statutory authorities were made up of local landowners whose properties were serviced by a particular secondary drain. Drainage Unions had the ability to tax local landowners for the maintenance and improvement of secondary drains and were able to carry out drainage works without prior state or local government approval. The NSW water reforms of 2000 have led to the abolition of many Drainage Unions, although some were replaced by Drainage Boards.

Farm-level, tertiary field drains, feeding into secondary drains, were constructed and maintained by individual landholders. Over $5000 \mathrm{~km}$ of drains have been constructed in coastal NSW. Both secondary and tertiary drains often have one-way floodgates to prevent tidal ingress of brackish and saline water. Floodgates are major impediments to fish passage to feeding and breeding areas. Until the introduction in 1997 of model provisions in specific Local Environment Plans (LEPs), there was little constraint on construction of tertiary drains in NSW.

Floodplain drainage and flood mitigation structures permitted the widespread establishment of grazing, dairying, tea and sugarcane industries in coastal eastern Australia. Table 1 gives details of the NSW sugar industry which intensively farms the three major coastal river floodplains in northern NSW. Almost all of this floodplain development was carried out without knowledge of the existence of acid sulfate soils within coastal floodplains or the potential impacts of their drainage. It is emphasised that governments of all political persuasions and levels through policy and legislation encouraged coastal floodplain development in eastern Australia.

\section{Impacts of drainage of coastal acid sulfate soils}

Many coastal floodplains throughout the world have Holocene-age $(<10,000$ y BP) sediments that contain iron sulfide mineral deposits [22], mostly rich in the mineral pyrite but, in some regions, monosulfides are important [23]. It is estimated that there are between $10^{7}$ and $10^{8}$ ha of Holocene sulfidic lowlands, known as acid sulfate soils, in coastal zones around the world, with large deposits in Southeast Asia, the

Table 1

Selected details of the NSW sugar industry

\begin{tabular}{ll}
\hline Characteristic & Value \\
\hline Number of farmers/farms & 640 \\
Number of direct/indirect employees & 2200 \\
Area farmed & $360 \mathrm{~km}^{2}$ \\
Total annual cane yield (2003) & $2.21 \times 10^{6}$ tonnes \\
Total annual sugar produced (2003) & $2.76 \times 10^{5}$ tonnes \\
Regional economic output & $\$ \mathrm{~A} 230 \times 10^{6}$ \\
Year NSW Sugar Milling Co-op formed & 1978 \\
\hline
\end{tabular}


Far East, Africa and Latin America [24]. When drained or exposed to air during prolonged dry periods, sulfides in the sediment are oxidised to sulfuric acid. Acid then leaches iron, aluminium, silica and other metals from soils making soil water toxic for plant and fish species. Detrimental impacts of drainage and oxidation of acid sulfate soils include: decreased plant growth, plant deaths and changed plant ecology [22]; corrosion of engineering infrastructures [25]; massive fish kills and fish diseases [26-28]; dramatic changes in stream ecology $[18,26]$; blooms of harmful cyanobacteria [29]; and emissions of sulfur dioxide [30]. While fish kills can occur naturally in acid sulfate soil areas [31-33], constructed drainage of floodplains has exacerbated the problems. Acidic outflows can also threaten aquaculture [34] and exported acidic materials can be sequestered in the sediments of shallow receiving waters where they are available for subsequent remobilisation [35].

Hundreds of tonnes of acidic products can be discharged from a floodplain in a single flood event $[19,36,37]$ and acid discharges from drained areas can persist for decades [25]. Deleterious impacts from the drainage of coastal acid sulfate soils have been reported in the Netherlands [38], Vietnam's Mekong Delta [36,39], China's Pearl River Delta [40,41], Indonesia [42,43], Finland [44,45], and the United States [46].

\subsection{Acid sulfate soils in Australia}

Acid sulfate soils were recognised in Europe over 250 years ago [38]. In Australia, their existence was appreciated only relatively recently $[31,32,47-50]$. Indeed, prior to the release of NSW acid sulfate soil risk maps in 1995 [51], acid sulfate soils did not officially exist in Australia. As recently as 2002, some Australian states denied their existence even though there are over $40,000 \mathrm{~km}^{2}$ of coastal acid sulfate soils distributed along coastal zones in every state of the Australian Commonwealth (see Fig. 1).

Walker [49], in his comprehensive study on the Macleay River floodplain, specifically warned of the dangers of continuing to drain sulfidic coastal floodplains in eastern Australia. His advice was ignored. Both management and research agencies had a longstanding preoccupation with the problems of inland agriculture that discouraged attention on the problems of coastal areas. The current widespread recognition, policy and strategies and guidelines on acid sulfate soils in Australia all stemmed from a single incident.

\subsection{Fish kills on the Tweed River}

Heavy rains in early 1987 following a prolonged dry period strongly acidified the entire $23 \mathrm{~km}$ of the Tweed River estuary (selected characteristics of the Tweed catchment are listed in Table 2) in northeastern NSW which drains to the sea at Tweed Heads. Dissolved aluminium completely clarified the normally turbid estuary and all gilled organisms were killed in massive numbers [26]. Possibly more than a 1000 tonnes of dissolved and colloidal aluminium was discharged in the event and the river remained almost sterile for a further 18 months. Approximately $11.5 \%$ of the catchment contains acid sulfate soils (Table 1).

The region surrounding the Tweed River is one of the fastest growing population centres in Australia (annual population growth rate about $2.4 \%$; see Table 2) because of is favourable climate, highly prized natural amenities and its highly productive volcanic soils. It is a major centre for tourism and recreational fishing. Nearly $70 \%$ of the commercial fish species caught in Australia spend part of their lives in estuaries. Oyster

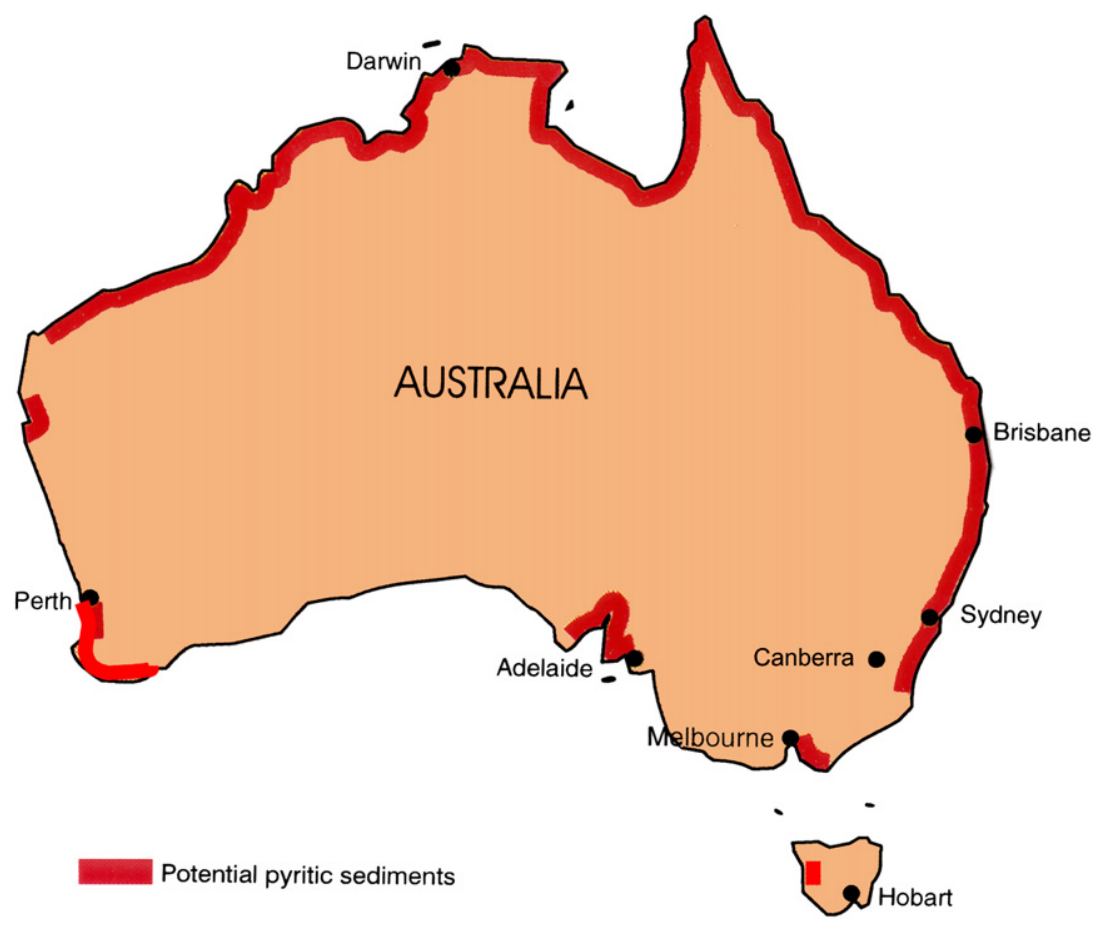

Fig. 1. An early attempt to identify the potential location of acid sulfate soils in the Australian coastal zone from the distribution of mangroves [25]. 
Table 2

Selected characteristics of the Tweed River catchment

\begin{tabular}{ll}
\hline Characteristic & Value \\
\hline Mean annual rainfall & $1650 \mathrm{~mm}$ \\
Mean annual pan evaporation & $1500 \mathrm{~mm}$ \\
Mean annual runoff & $6.3 \times 10^{8} \mathrm{~m}^{3}$ \\
Length of river & $80 \mathrm{~km}$ \\
Length of estuary & $23 \mathrm{~km}$ \\
Catchment area & $1025 \mathrm{~km}^{2}$ \\
Floodplain area & $117 \mathrm{~km}^{2}$ \\
Area high risk ASS & $97 \mathrm{~km}^{2}$ \\
Area sugar cane & $73.1 \mathrm{~km}^{2}$ \\
Area other crops & $19.7 \mathrm{~km}^{2}$ \\
Area grazing & $437 \mathrm{~km}^{2}$ \\
Area urban development & $32.8 \mathrm{~km}^{2}$ \\
Total cleared area & $563 \mathrm{~km}^{2}$ \\
Area native forest & $462 \mathrm{~km}^{2}$ \\
Percent catchment cleared & $55 \%$ \\
Total population (2001) & 73,821 \\
Catchment population density & $72 \mathrm{persons}^{2} \mathrm{~km}^{2}$ \\
Population growth rate (1991-2001) & $2.4 \% / \mathrm{year}$ \\
Annual value of sugarcane & $\$ \mathrm{~A} 12.4 \times 10^{6}$ \\
Annual value of other crops & $\$ \mathrm{~A} 13.3 \times 10^{6}$ \\
Annual value of fisheries & $\$ \mathrm{~A} 0 \times 10^{3}$ \\
Annual value of tourism/recreation & $\$ \mathrm{~A} 150 \times 10^{6}$ \\
\hline
\end{tabular}

farming is also practiced in many estuaries. The fish kills on the Tweed attracted major media coverage. Over $62 \%$ of the 11,700 ha Tweed River floodplain is used for sugarcane production (see Table 2). A plethora of reasons were advanced for the fish kills and sugarcane farming was implicated in most of them. At first, pesticides were suspected as the cause of fish kills but a Tweed Shire Council entomologist noticed that mosquito larvae had not been killed by the event [26]. Instead he showed that the fish kills were due to acidic, aluminium-rich drainage from acid sulfate soils which made up much of the floodplain.

The 1987 fish kills on the Tweed provoked serious conflicts, particularly between commercial and recreational fishers, tourism operators, oyster farmers and environmentalists and the cane farming industry. Production in the NSW oyster industry had declined markedly over the period of recent floodplain development. Livelihoods on both sides were threatened. An initial public meeting of 500 locals ended in acrimony with threats to blow up or vandalise tidal floodgates on drains and inundate farmlands with brackish estuarine water, and counter threats to shoot trespassers who interfered with drainage structures. One week later, the parties reconvened with cooler heads and elected representatives from each stakeholder group. This body became the Tweed River Advisory Committee, TRAC.

\section{Evolution of a cooperative learning partnership}

\subsection{Foundations of participation}

In an attempt to find a formal way forward, the local government, Tweed Shire Council, convened a meeting of key representatives from TRAC in 1989. The meeting included farmers and fishers, oyster farmers, representatives from local government and NSW State resource agencies and scientists from university and Commonwealth research organisations. At the time there were only three scientists in Australia with significant research experience in acid sulfate soils.

The initial aim of the Tweed meeting was to determine the cause of the fish kills and to explore possible solutions. Extravagant claims and counterclaims were made on both sides. The then six NSW State government agencies with responsibilities for estuarine management were wary of issues connected with coastal development, which was, and continues to be a major, controversial political question. Tweed Shire Council helped foster the development of a local acid sulfate soil committee composed of the conflicting parties, local government and researchers in 1990. A consensus was finally agreed by all parties that existing information on the fish kills was incomplete. Research to investigate the processes causing the water quality problems was required.

\subsection{Adequacy of understanding}

In 1990, when research on the Tweed commenced, there was a considerable body of overseas knowledge about acid sulfate soils and some of the general principles of their safe management were well established [22]. However, there were significant knowledge gaps in the Australian context with its extremely variable climate and hydrology. One of the principle issues raised by the committee was the comparative contribution of natural and of farming-related processes to acid discharge.

The Tweed River catchment was particularly attractive to researchers because: there was essentially a single land use on the sulfidic floodplain, sugarcane production; the sugarcane industry was a well structured cooperative so that results of research are readily transferable; the catchment was managed by a single local government. As well Tweed Shire Council was determined to find workable solutions to land use and estuarine water quality problems under their jurisdiction.

Much of the previous work on acid sulfate soils had focussed on improving their agronomic productivity [22], mainly due to experience in areas where the assimilation capacity of receiving waters exceeded the export rate from drains or where off-site environmental impacts were discounted. Very little attention had been paid to the downstream and off-site impacts when developing acid sulfate soils for agriculture [49]. The existing knowledge in 1990 suggested that acidic exports from acid sulfate soils were the result of continuing oxidation of pyrite. With that model, in order to stop the export of acidity, air must be prevented from entering the sulfidic horizon, most usually by reflooding the soil or by raising the groundwater level above the sulfidic horizon. This was expected to reverse the acidification processes by reducing oxidised sulfate back to sulfides through the microbially catalysed oxidation of organic matter [22]:

$$
\begin{aligned}
& 4 \mathrm{FeOOH}(\mathrm{s})+4 \mathrm{SO}_{4}^{2-}+9 \mathrm{CH}_{2} \mathrm{O}+8 \mathrm{H}^{+} \rightarrow 4 \mathrm{FeS}(\mathrm{s})+9 \mathrm{CO}_{2} \\
& +15 \mathrm{H}_{2} \mathrm{O}
\end{aligned}
$$


Reflooding of sulfidic floodplains is still the most common management strategy recommended for acid sulfate soils. There was also a general perception that lengthy, detailed and expensive soil mapping was required to determine the distribution of acid sulfate soils in floodplains.

Armed with this set of beliefs, research commenced on the Tweed in early February 1990. Monitoring by the Tweed Shire Council had identified McLeods Creek (a re-engineered secondary drainage canal maintained by the McLeods and Leddys Creek Drainage Union) catchment as one of the acid exporting 'hotspots' on the Tweed River. It was clear from even preliminary measurements that the site did not conform to conventional wisdom. One feature of the farmed floodplain was the complex, dense and seemingly over-constructed farm-level drainage system excavated without engineering drainage design.

\subsection{Distribution of acid sulfate soils}

Determination of the spatial extent of acid sulfate soils in the Tweed River floodplain was fundamentally important to improved management. Conventional soil survey would have taken too long and was beyond the participants' resources. A geomorphic approach to mapping based on the conditions necessary for sulfide accumulation in Holocene estuarine sediments was developed. Over the last 6500 years, global sea level has remained fairly constant, the eastern Australian land surface has been tectonically relatively stable over that time, and fluvial sediment accumulation there has not been large [18].

Based on these, the top of the sulfidic horizon in Australian Holocene coastal sediments should be close to where it was last formed, at about mean high tide level (about $1 \mathrm{~m}$ AHD in eastern Australia). Because this horizon has been buried by a variable thickness of alluvium, it was predicted that Holocene coastal sulfidic sediments in eastern Australia would be found at sites with surface elevations of less than about $5 \mathrm{~m}$ AHD [52-54]. This prediction provided the basis for production of acid sulfate soil risk maps for the entire state of NSW [51]. Acid sulfate soil risk maps were based on the depth below the soil surface of the sulfidic horizon. Fig. 2 shows the distribution of acid sulfate soils in the NSW coastal zone and Fig. 3 shows the acid sulfate soil risk map for the Tweed. These maps have been remarkably accurate and useful planning tools and form the basis for Local Environment Plans Development Control Plans and Development Assessment that control developments in acid sulfate soil areas in NSW.

\subsection{Cane farmers' response}

Initial discussions between researchers and cane farmers in the McLeods Creek catchment and sugar mill officers during the preliminary site visit were less than encouraging. The cane industry rejected the suggestion that acidification of streams was attributable to their soils, some suggesting instead that it was road gravel that caused the problem. Some argued that there had always been fish kills, long before floodplain drainage. Others believed that acid sulfate soils were just a convenient vehicle for generating jobs for academics and bureaucrats. Most resented the media's sensationalising of fish kills and their portrayal of farmers as environmental vandals. It also emerged that the industry wanted to lower water tables further by up to $1 \mathrm{~m}$ to improve cane production, since waterlogging was perceived to be a main impediment to cane production.

Cane farmers were divided on whether researchers should be invited into the catchment. The strong opposition was understandable since the prevailing wisdom was that, in order to control acid discharges, low-lying areas should be reflooded with brackish estuarine water, thereby eliminating cane production, farmers' livelihoods and property values. In addition, farmers felt they were being blamed unfairly for acidic drain discharges from areas that they had developed for agriculture with continued encouragement from governments.

Despite their misgivings, farmers at McLeods Creek gave permission for researchers to work on their lands. The support of Tweed Shire Council for continued research and monitoring was a crucial element in persuading farmers to tolerate research directed at understanding the processes involved in the generation and export of acidity and its environmental impacts and at identifying amelioration strategies.

\subsection{Cooperative learning}

In the early days of research on the Tweed, there was some mutual mistrust between researchers and farmers. The culture and reward systems for both groups differ fundamentally. It took 4 to 5 years for mutual understanding and trust to develop. This gradual evolution was assisted by both the continued interest support of local government staff and State level initiatives in acid sulfate soils.

Researchers initially had a narrow focus on exploring and publishing on soil [53], hydrological [55] and environmental issues $[27,56]$. Work had also expanded into the more complex and larger Richmond River floodplain south of the Tweed where there were also major acid discharges and fish kills (see Fig. 4 [19]). Researchers began to appreciate that acid sulfate soil management was but one of a very broad range of issues that had to be faced and dealt with by farmers and by local governments. They recognised that farmers and regulators have to deal with and integrate a bewildering range of soil, climate, crop, nutrient, disease, pest, social, regulatory, financial, political and institutional issues in their daily tasks. It became increasingly apparent to researchers that they needed to understand these broader issues in order to transfer their research findings effectively.

Frequent, informal discussions were held in the field where both research results and information on the current issues faced by farmers and local government were exchanged. These were interspersed with more formal meetings with the NSW Sugar Industry and Tweed Shire Council representatives and various committees such as the Tweed River Management Plan Advisory Committee. It became increasingly clear to researchers that one of their tasks was to provide a range of practical management options for farmers and regulators, not single prescriptive solutions. 


\section{Extent of acid sulphate soils in NSW}

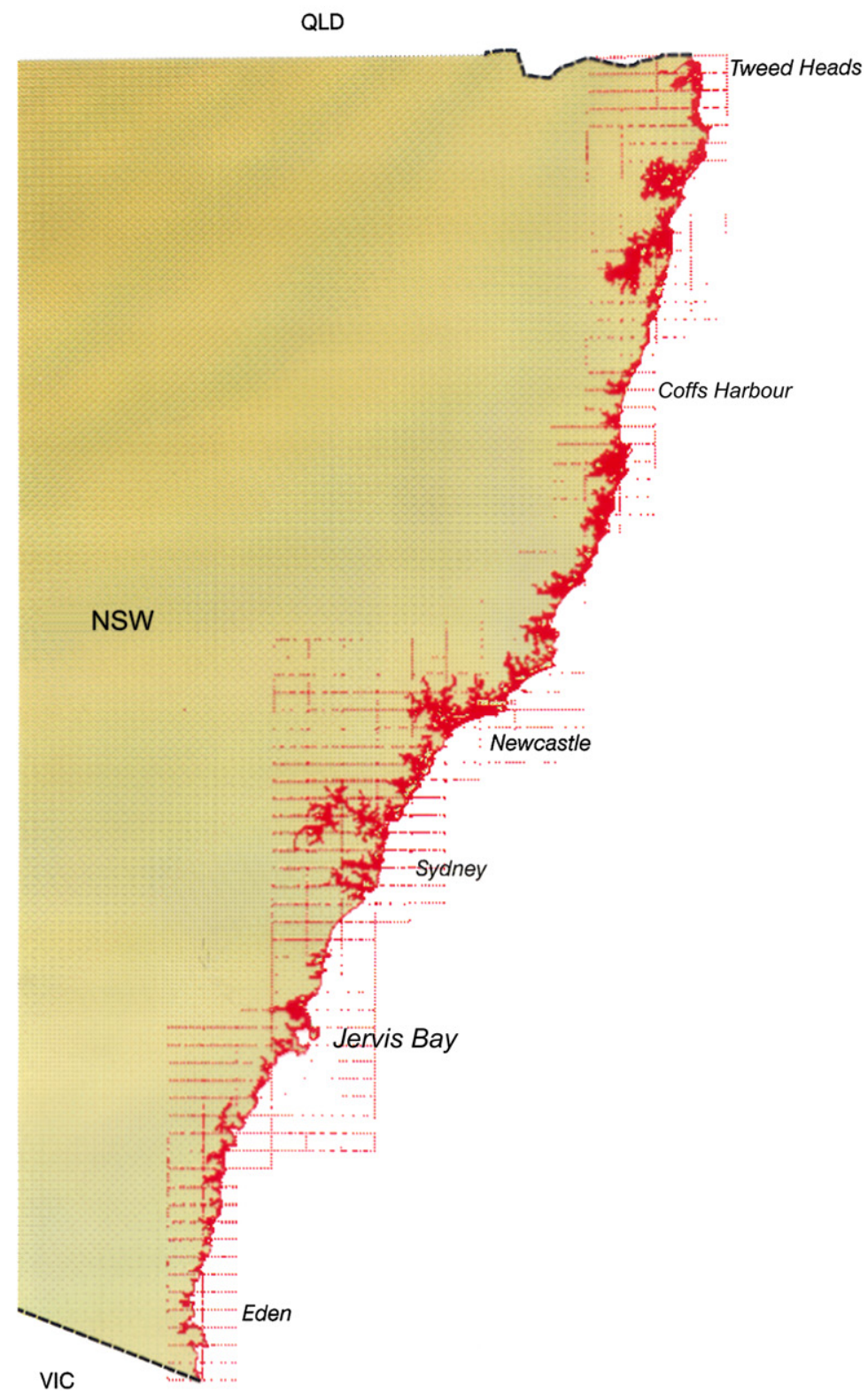

Fig. 2. Risk map of the distribution of acid sulfate soils in eastern Australia's state of New South Wales [51]. The Tweed River discharges to the ocean at Tweed Heads.

The training of postgraduate students and postdoctoral fellows in acid sulfate soil and related field research was a key component in the developing partnership. It has been an invaluable opportunity for cooperative training. Graduate students and postdoctoral fellows are highly motivated and can focus on key issues exclusively. They are also less threatening to farmers than senior researchers. The opportunity for them to research in partnership with experienced farmers is an unparalleled, two-way, learning opportunity. Additionally, there remains a real dearth of people with field-integrated experience in coastal soils, hydrology, environmental impacts and land management in Australia.

Farmers also began to appreciate that researchers were not there to apportion blame. Indeed, researchers' message that acid sulfate soils were part of the global sulfur cycle, a naturally occurring phenomena that has existed for hundreds of millions of years, brought about a shift in attitude. Farmers started to talk about their acid sulfate soils and to carry $\mathrm{pH}$ meters. Once that happened, farmers became not just partners but initiators of the research.

\subsection{Collaborative research findings}

Some of the research findings in the Tweed were counter to the prevailing wisdom and resulted in significant land management changes. During dry periods, it was found that cane crops survive on shallow groundwater [55]. The industry's quest to further lower water tables by increasing drain depths 


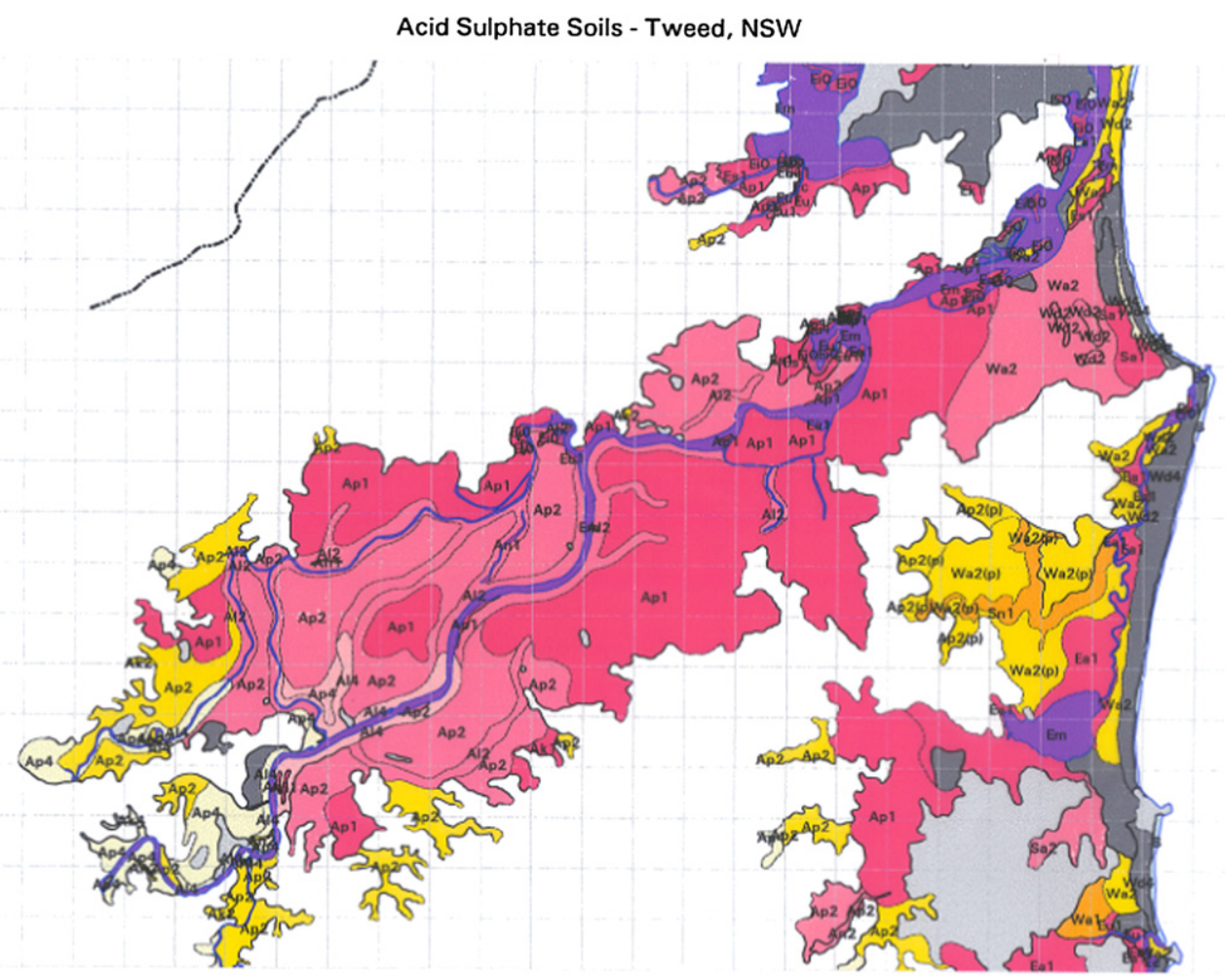

Fig. 3. Acid sulfate soil risk map of the Tweed River floodplain. Shading on the map represents the depth to the sulfidic horizon from the soil surface [51].

would result in decreased crop production. In addition the shrink-swell nature of the sulfidic soil sublayer $(80 \%$ by volume water) dictates that lowering the water table also lowers the elevation of the soil surface [57].

Because of the exceedingly small hydraulic conductivity of the unoxidised sulfidic clay $[55,58]$ crop evapotranspiration

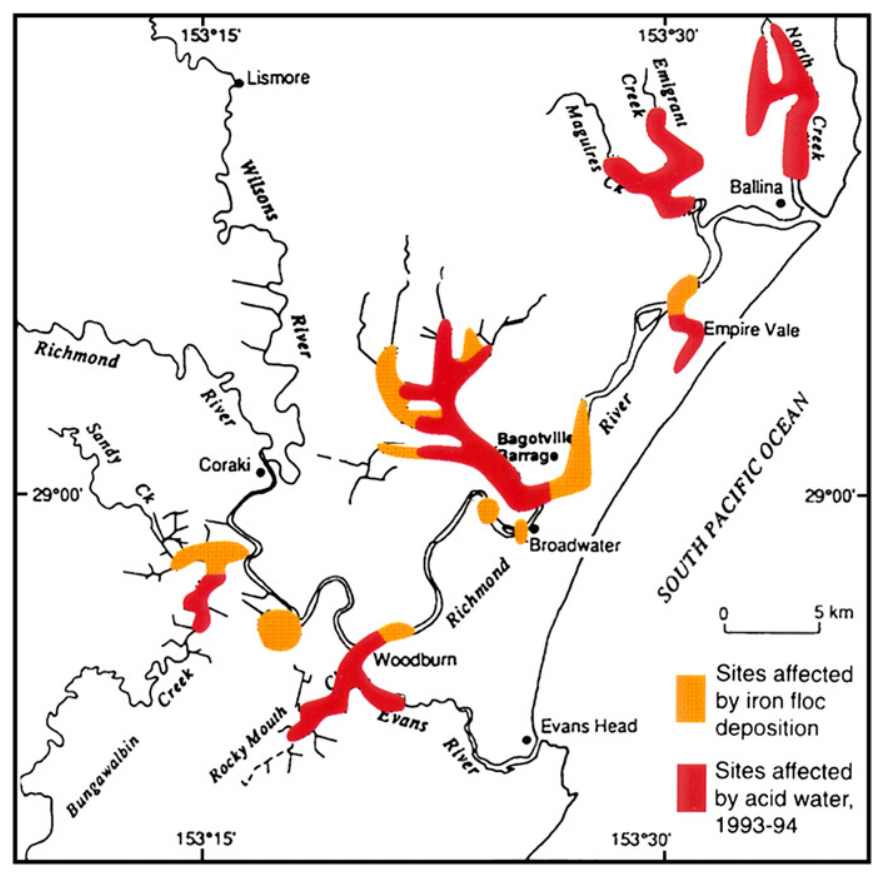

Fig. 4. Extent of acid-impacted areas in the Richmond River estuary in 19931994 from drainage of acid sulfate soils [19]. was the main determinant of water table level, not drainwater level. The predominant water flow in these low relief landscapes, with subsoils with almost negligible horizontal transmissivity, was vertical. This meant that drains were essentially disconnected from the water table in cane blocks and implied that the prime function of drains is to remove surface water following floods and heavy rains, not to control water table elevation. By using laser levelling to improve the shedding of surface water, waterlogging could be reduced and drain depth and density decreased [17].

The research also shed light on a major source of acidity exported from acid sulfate soils. Vast quantities of existing acid products, equivalent to about 50 tonnes/ha of sulfuric acid, from previous oxidation of sulfides and subsequent reactions with the soil, were found stored within the subsoil above the sulfidic layer $[59,60]$. The highest levels of stored acidity in the floodplain follow former, natural drainage lines [59]. This is consistent with the observation that most exported acidity is sourced from a few metres around drains [17,61] and is readily released during the recession phase of floods, independent of any further oxidation of sulfides [37]. Some of the exported, metal-rich acidic drainage products were found to be stored as iron monosulfide in the drain bottom sediments $[19,62]$; others were sequestered in shallow sediments in receiving water bodies [35]. The average flux of acidic products from drained floodplains (as sulfuric acid) was estimated to be between 0.3 and 0.5 tonnes/ha per year [19,37], although some oxidation products are exported in the atmosphere as $\mathrm{SO}_{2}$ [30]. The store of acidic products in the soil has accumulated from more than just the influence of constructed drainage. Some is the result of 
severe droughts [18] and some appears due to small isostatic uplift of the east coast of Australia [61].

These findings changed the focus of management from the prevention of sulfide oxidation to the retention of as much of the stored acidity within the soil-drain system by manipulating the volumes of surface runoff and flood recession flow volumes. In addition decreasing drainage density also profoundly decreases acid export. The collaborative research led to the development by farmers of new goals for drainage management. These were to leave as much of the stored soil acidity in the floodplain as possible and to prevent the development of any additional acidity.

\section{Changed land management}

Because the research was being carried out in a cooperative learning process, long before research was published, the farmers in McLeods Creek catchment were able to change land management strategies, where appropriate. Researchers were amazed by the rapid implementation by farmers of even preliminary research findings on management strategies, particularly since implementation often meant the expenditure of significant farmer funds. Farmers, however, later explained that they weighed information very carefully before implementing any changed management practices.

An early application of the research was that farmers abandoned their plans for increased drainage. Instead the focus was on control and rapid removal of surface water. Progressive laser levelling of cane fields was undertaken. This enabled the removal of tertiary field drains, in some cases the drainage density was decreased by a factor of two and drain depth was decreased. The decrease in drain density meant that more land was available for cane planting. Places in cane blocks where prolonged ponding of surface water occurred were eliminated. In addition, the construction of new drains was avoided. Lime was added to drainage lines and to cane fields at a rate that exceeds the mean annual rate of acid production.

The improved removal of surface water meant that the better quality water during the rising limb of the hydrograph could be safely discharged into streams. Farmers then stored within drains as much as possible of the acid groundwater discharged during the recession phase. Farmers also trialed a range of options to treat acidic drainwater before discharge. Techniques included the lime dosing of drainwater, discharge of drainwater through closed-tank lime-bed reactors and discharge through constructed wetlands. As well, farmers modified tidal floodgates to permit their opening in dry periods to allow both tidal exchange with drainwater and increased fish passage.

Farmers recognised that the availability of organic matter was a key to driving the oxidation reaction backward (Eq. (1)). They have trialed green cane harvesting with the retention of surface cane trash to increase organic matter availability. Trash retention was coupled with the using 'raised beds' (ridges and furrows) for cane production.

These changes came at a considerable cost to landowners and were only possible because of the relatively high per hectare returns of sugar production. Farmer-initiated trials have found about a $10 \%$ increase in cane yield with lime use in some soils. As well, removal of drains has increased the area for cane planting. The net result of these changes has been up to $30 \%$ increase in production. While the episodic nature of acid discharges makes it difficult to precisely estimate changes in acidic exports, recent results suggest that the above strategies have decreased the flux during one in two year floods by $90 \%$.

\subsection{Benchmarking farmer attitudes and knowledge}

In May 1998, a study was conducted of 287 farmers from the cane, beef, dairying and tea tree industries from seven catchments on the NSW coast to determine their knowledge of best management practices for acid sulfate soils [63]. The median size of cane properties owned by farmers in the survey was $80 \mathrm{ha}$, comparable to that for dairy ( $85 \mathrm{ha}$ ) and for tea tree farms ( $81 \mathrm{ha}$ ) but larger than that for beef $(68 \mathrm{ha})$. Cane farmers obtained $86 \%$ of their income from their farms, while the percentage for diary was $95 \%$. In contrast, tea tree and beef made respectively only $78 \%$ and $52 \%$ of their income from their farms.

The survey found the sugar industry was ahead of the other farming industries in its awareness and knowledge levels. This was partly attributed to the geographic closeness of the industry, its cohesiveness (as a farmer-owned cooperative) and the then relatively stable commodity prices providing good returns. Approximately $60 \%$ of all cane farmers surveyed had high awareness of acid sulfate soils. More cane farmers had their soil tested and used lime (80\%) than in the other farming industry groups. It was concluded on the Tweed, cane farmers had a high knowledge of acid sulfate soils because of the investment of the industry, farmers and scientists in on-farm trials, soil sampling, education and changed management practices.

A follow-up farmer survey in 2002 [64] showed that cane farmers had been more active than other farm industries in filling in drains (57\%) or reshaping drains (34\%). On the Tweed, those figures were over $70 \%$ and $30 \%$ respectively.

\subsection{Development of wise use agreements}

The above changes in land management in the Tweed floodplain had the approval and support of the Tweed Shire Council. There was only limited interest in other acid sulfate soils catchments in NSW on adoption of land use changes, partly because of the multiplicity of land uses in the catchment and partly because of disinterested local governments. It was recognised that some form of regulation was necessary to prevent further acidification of coastal floodplains. The statutory instrument chosen was Local Environment Plans (LEP) [64] to be promoted by the State and developed and administered by local government. It soon become clear that introduction of an LEP would result in development controls on even the most trivial of farming activities. The solution proposed by the NSW Cane Industry was self-regulation and the industry commenced developing the NSW Sugar Industry Best Practice Guidelines for Acid Sulfate Soils in collaboration with Tweed 
Shire Council, cane farmers, state authorities and researchers. Planning NSW, the state consent authority approved a Memorandum of Understanding with the industry and appointed the NSW Sugar Milling Cooperative, in conjunction with local governments, to be the consent authorities. Planning also provided for local government and relevant state authorities to undertake strict annual audits and reviews of the adherence by selected individual farmers to the guidelines. The cooperative research on the Tweed and an acid sulfate soil survey by the industry of all farms provided the basis for the guidelines. The soil survey had the additional benefit of raising awareness of acid sulfate soils amongst cane farmers in other catchments [65]. The best management practice guidelines were introduced in May 2000.

The intended purpose of Best Practice Guidelines is to provide guidelines, based on the best available information, for cane farmers with acid sulfate soils in order that they:

- minimise the export of acidity from their farms;

- minimise any downstream environmental impacts caused by acid export;

- maximise production from their land; and

- adhere to the intent of Local Environment Plans on acid sulfate soils.

Unlike voluntary wise use practice agreements [2,14] the NSW Sugar Industry Best Practice Guidelines for Acid Sulfate Soils are mandatory. They involve annual review of compliance and, because the Sugar Milling Cooperative is a cane farmer-owned cooperative, it refuses to accept or pay for cane from land not managed according to best practice.

A follow-up survey of farmer attitudes in 2002 [64] observed that $98 \%$ of cane farmers knew the depth of acid sulfate soils on their properties. The survey concluded that the majority of cane farmers believed that the LEP regulations were about right. Cane farmers were found to be proud of their best practice environmental guidelines and the self-regulation and auditing systems. They were confident their industry had acid sulfate soils under control. Their positive commitment to the Best Management Guidelines is reflected in the continued high level of compliance in Table 3 found by independent audits of randomly selected sugarcane farms conducted jointly by the NSW government and Tweed Shire Council. This audit process is a key strategy in self-regulation.

\section{Parallel developments: from whole-of-government to national strategy}

In parallel to the work on the Tweed, progress was occurring simultaneously at the State and belatedly at the national levels. Societal concern about fish kills caused by acid sulfate soil drainage spread rapidly throughout NSW and into neighbouring Queensland. The commercial fishing industry used fish kills, as an indicator of general malaise in coastal and estuarine management in eastern Australia. It made effective use of the media, raising public awareness of the problems and helping spread concerns to other regions.
Table 3

Results of independent audits of compliance of randomly selected sugarcane farms with the NSW Sugar Industry Best Practice Guidelines for Acid Sulfate Soils

\begin{tabular}{lll}
\hline Year & $\begin{array}{l}\text { No. of } \\
\text { farms } \\
\text { audited }\end{array}$ & $\begin{array}{l}\text { No. of } \\
\text { farms 100\% } \\
\text { compliant }\end{array}$ \\
\hline 2001 & 30 & 27 \\
2002 & 30 & 29 \\
2003 & 30 & 30 \\
2004 & 30 & 30 \\
\hline
\end{tabular}

Faced with conflict in his portfolio between farmers and fishers, the NSW Minister for Agriculture and Fisheries, in 1994, formed a whole-of-government Acid Sulfate Soil Management Advisory Committee (ASSMAC) to provide him with advice on the use and management of acid sulfate soils. ASSMAC initially had representatives from the five government agencies with significant responsibilities in coastal regions and from the NSW Farmers Association, the seafood industry and the research community. Membership later broadened to include all the significant coastal industries including the oyster, sugarcane, dairying, tea tree and urban development industries [66]. The predominant focus of ASSMAC, however, was on agricultural impacts, solutions and strategies, since the predominant developments on acid sulfate soil were agricultural.

Tensions between the farming and fishing industry representatives were apparent, as were differences in approach between management and regulatory State agencies. Faced with these tensions, ASSMAC developed a strategic approach whose main goals were the prevention of further disturbance of acid sulfate soils, and the remediation of existing problem areas. ASSMAC's approach had four objectives to:

1. Raise awareness of the occurrence and properties of acid sulfate soils,

2. Promote education about their properties and use,

3. Sponsor appropriate research on their management and remediation, and

4. Explore the adequacy of policy and legislation.

These key objectives have been carried over into other states and into the national strategy.

Because acid sulfate soils were unmapped in Australia, an essential, early essential task in this strategic approach was the production and promotion of acid sulfate risk maps for the entire NSW coast in 1995 [52] (Figs. 2 and 3). These revealed NSW had about $4000 \mathrm{~km}^{2}$ of high-risk acid sulfate soils. Other information activities included publication of acid sulfate soil management guidelines in 1995 [67], educational and publicity materials and a national and international newsletter, ASSAY. Because of the different character of land uses in coastal catchments, practical solutions to the management and use of acid sulfate soils could only be generated at the local level. ASSMAC therefore encouraged and supported the formation of acid sulfate soil local action groups in other estuaries modelled on the committee set up by Tweed Shire Council in 1990. 
To measure the impact and effectiveness of its strategies, ASSMAC commissioned benchmarking surveys in 1998 and $2002[63,64]$ to determine farmer knowledge of best management practices for acid sulfate soils. Key changes between the two surveys were that: the percentage of all farmers aware of acid sulfate soils had increased from 45 to $85 \%$; the percentage aware of acid sulfate soil risk maps had increased from 55 to $85 \%$; and conflict has been reduced. The 2002 survey observed that ASSMAC had stimulated debate and had facilitated knowledge transfer between scientists, policy makers and farmers. The survey concluded that a single government agency could not have accommodated the scope of views or ownership nor could it have generated the level of debate amongst non-government organisations.

Existing laws in NSW were found to be adequate to prevent increased acidic discharge from acid sulfate soils. However, without a specific regulatory instrument, continued land disturbance was possible. A State government mandated planning process was initiated that required local governments to develop a LEP, covering the disturbance of acid sulfate soils. A model LEP, based on the published acid sulfate soil risk maps, was developed in consultation with coastal councils, government agencies and stakeholders [66].

In 1997, ASSMAC initiated the Acid Sulfate Soils Program (ASSPRO) to fund research into the remediation of problematic acid sulfate areas in the State. ASSMAC commissioned a study identifying acid sulfate soil 'hot spots' in estuaries, those areas likely to be contributing disproportionately to acid fluxes. This study formed the basis of a 1999 Hot Spot Program designed to remediate these problem areas.

Major structural rearrangements in natural resource management in NSW resulted in the establishment of Catchment Management Authorities and the Natural Resources Commission in 2004 and in the abolition of ASSMAC and the evaporation of Hot Spot funds. The impetus for change in acid sulfate soil management has been set back by this shift in government natural resource management. Other Australian state jurisdictions that are making progress are managing acid sulfate soils as a specific issue and seeking support from regional service delivery organisations.

As part of its strategic approach, ASSMAC encouraged the establishment of a similar body in Queensland, QASSMAC, which by 1995 , had finally admitted that it also had acid sulfate soils. The focus of QASSMAC, unlike the agricultural thrust of ASSMAC, has been largely on urban development on acid sulfate soils. ASSMAC and the fishing industry also lobbied for the development of an Australian-wide strategy on acid sulfate soils. The Commonwealth's then Standing Committee on Agricultural and Resource Management formed a national working party in 1998 to develop a national strategy for the management of coastal acid sulfate soils. This national strategy was accepted and released by both the Agricultural and Resource Management Council of Australia and New Zealand, the Australian and New Zealand Environment and Conservation Council and the Ministerial Council, Fisheries, Forestry and Aquaculture in 2000.

The national strategy aims to improve the management and use of coastal acid sulfate soils in Australia, to protect and improve water quality in coastal floodplains and embayments, and to assist governments, industry and the community in identifying and undertaking their roles in managing coastal acid sulfate soils. To achieve these aims the strategy has four principal objectives:

1. Identify and define coastal acid sulfate soils in Australia.

2. Avoid disturbance of coastal acid sulfate soils.

3. Mitigate impacts when acid sulfate soil disturbance in unavoidable.

4. Rehabilitate disturbed acid sulfate soil and acid drainage.

The relation between these objectives and ASSMAC's strategic approach is apparent. The National Committee on Coastal Acid Sulfate Soils, NatCASS, with responsibility for carriage of the national strategy, has been very effective. It acknowledges that ASS presents a different suite of problems at each location but believes that national coordination can greatly accelerate knowledge transfer. It has catalysed the rapid and effective transfer of knowledge and expertise from ASSMAC and QASSMAC to regulators, developers and users in other States and Territories, where the problem has only recently been recognised.

The NatCASS network provides support to those officials who have to present the facts to governments and industry unwilling to acknowledge the problem. Data and experience from around Australia is readily available through this network. This expertise includes mapping, extension techniques and material, statutory policy for development on ASS, research into management principles and technologies, and rehabilitation of ASS in coastal and urban environments. It has also facilitated the development of national standards for laboratory analytical techniques and field investigation procedures. The ASS national strategy is an important component of the national integrated coastal management policy administered by the Marine and Coastal Committee on behalf of the NRM Standing Committee and Ministerial Council.

Australia now has better informed governments, communities and industries capable of properly managing ASS. While some locations are still in the denial phase, the warnings of Pat Walker [49] on the care necessary with the development of ASS are finally being heard.

\section{Conclusions}

In global terms, agriculture exerts a major influence on water quality and ecology in estuaries and near shore environments. Non-point pollution represents one of the major challenges in sustainable land and water management. Some of the key challenges in decreasing degradation in coastal zones are the provision of appropriate information, fostering of participatory processes entraining communities of interest and the development of wise practice agreements and best management practices for better land use and water quality outcomes. Diffuse source discharge of nitrogen, dissolved carbon and increased sediment loads are of major global concern [51]. We have shown that acidic discharges 
from recent acid sulfate soils can also have major, long-term impacts in estuaries.

Massive fish kills from acid sulfate soil floodplains in eastern Australia, drained with government encouragement, generated conflicts between coastal resource users that eventually led to the development of a cooperative learning approach involving farmers, local government and researchers. That approach resulted in both improved water quality and increased crop production and led to self-regulation and a mandatory, wise use agreement, between the NSW sugar industry and the State and local governments. Annual independent monitoring of compliance is a key component of the agreement. As well, fish kills catalysed a whole-of-government-resource-user approach that resulted in the generation and wide dissemination of information and strategies and led to the development of a national strategy on the management of acid sulfate soils.

Some of the outcomes here are dependent on the particular institutions and governance arrangements for natural resources in Australia. However, we believe that there are some lessons that are applicable elsewhere. We have attempted to show that local government played a vital role in identifying the issues, in initiating the participation process and in providing support for the developing collaboration. Farmers belong to an industry that is a well-structured and profitable grower cooperative that fosters innovation. This ensured the rapid translation of collaborative research results into industry-wide practice. Researcher collaborators and students had a broad range of skills in soil science, hydrology, geomorphology, geochemistry, agriculture and environmental management. There were sources of funding to support the work and sufficient time for the partnership and trust to develop (time scale about 5 years). Regulation and policy frameworks existed that were directed at positive environmental outcomes. Lastly, the 1987 fish kills were a highly visible and widely publicised environmental impact that galvanised attention at all levels.

Many of the fundamental principles of participatory resource management [68] are evident in this case study, such as the importance of including stakeholders in joint inquiry, co-development of new resource management regimes, and the need to combine local and scientific knowledge and expertise. Other lessons emerging from the State-wide response are that a whole-of-government and industry approach, embodied in ASSMAC, was more effective in addressing problems caused by acid sulfate soils than approaches by individual agencies. There, a strategic approach with clear objectives based on consensus and cooperation, rather than heavy-handed application of existing regulations, brought about behavioural change which ASSMAC was able to quantify through its benchmarking monitoring. Focussing a whole-of-government effort on a single issue, such as acid sulfate soils, at a State level and fostering action at the local level appears to have been a far more effective approach than natural resource management reforms based on integrated catchment management.

Finally, the parallel development and acceptance of a national strategy on acid sulfate soils with objectives that evolved from ASSMAC has been very effective in coordinating a national focus on the problem. While recognising that
ASS presents a different suite of problems at each location, the strategy has catalysed the rapid and effective transfer of knowledge to States and Territories in Australia where the problems of acid sulfate soils are only just being recognised.

Finally, it is salutary to consider, after more than 30 years, the now-verified predictions of Walker [49] on the dangers of continued drainage of sulfidic coastal floodplains. It is clear that publishing in scientific journals is insufficient to transmit natural resource management information to bureaucrats, political decision-makers and resource owners and users.

\section{Acknowledgements}

This work has been generously supported by the Australian Research Council, ASSPRO, NSW Canegrowers, NSW Sugar Milling Cooperative, the Natural Heritage Trust, the Tweed River Management and Planning Committee, the Tweed Shire Council and Environment Australia's Coastal Acid Sulfate Soil Program.

\section{References}

[1] Costanza R, D’Arge R, de Groot R, Faber S, Grasso M, Hannon B, et al. The value of the world's ecosystem services and natural capital. Nature 1997;387:253-60.

[2] UNESCO. Wise practices for managing conflict situations, Continental coastal regions. Results of a workshop on 'Wise practices for coastal conflict prevention and solution', Maputo, Mozambique, 19-23 November 2001. Coastal region and small island papers. Paris: UNESCO; 2002.

[3] Kremer HH, Crossland CJ. Coastal change and the "Anthropocene". Past and future directions of IGBP-LOICZ project. In: Low-lying coastal areas - hydrology and integrated coastal zone management. International symposium, Bremerhaven Germany, 9-12 September 2002. Koblenz, Germany: Deutches IHP/OHP-Nationalkomittee; 2002. p. 3-19 (ISSN 0177-9915).

[4] WRI (World Resources Institute). World resources 2000-2001, People and ecosystems. The fraying web of life. Washington, DC: World Resources Institute; 2000. p. 389.

[5] Buddemeier RW, Smith SV, Swaney DP, Crossland CJ, editors. The role of the coastal ocean in the disturbed and undisturbed nutrient and carbon cycles. LOICZ reports and studies no. 24. Texel, The Netherlands: LOICZ; 2002. p. 83.

[6] GESAMP. A sea of troubles. GESAMP (IMO/FAO/UNESCO-IOC/ WMO/IAEA/UN/UNEP Joint Group of Experts on the Scientific Aspects of Marine Environmental Protection) Rep. stud. GESAMP No. 70, p. 35 and No. 71, p. 162; 2001.

[7] Dovers SR, Mobbs C. An alluring prospect? Ecology and the requirements of adaptive management. In: Bossemann K, Richardson B, editors. Environmental justice and market place mechanisms. London: Kluver International; 1999.

[8] Jiggins J. Interagency learning process. In: OECD Workshop on: An interdisciplinary dialogue: agricultural production and integrated ecosystem management of soil and water. Ballina 10-16 Nov 2002. OECD, Uni Western Sydney, NSW Agriculture; 2002. pp. 86-94.

[9] Harris GP. Comparison of the biogeochemistry of lakes and estuaries: ecosystem processes, functional groups, hysteresis effects and interaction between macro- and microbiology. Mar Freshwat Res 1999;50:791-811.

[10] Laser A. The Florida Keys Carrying Capacity Study as an example of land use planning and coastal management implementation. In: Lowlying coastal areas - hydrology and integrated coastal zone management, International symposium, Bremerhaven, Germany, 9-12 September 2002. Koblenz, Germany: Deutches IHP/OHP-Nationalkomittee; 2002. pp. 103-6 (ISSN 0177-9915). 
[11] Thom BG. Environmental history and decision making. Keynote address, 5th International acid sulfate soils conference, Tweed Heads, NSW, Australia; 26-30 August 2002.

[12] Furnham A. The psychology of change management. In: OECD Workshop on: An interdisciplinary dialogue: agricultural production and integrated ecosystem management of soil and water. Ballina 10-16 Nov 2002. OECD, Uni Western Sydney: NSW Agriculture; 2002. pp. 38-50.

[13] Thom BG, Harvey N. Triggers for late twentieth century reform of Australian coastal management. Aust Geog Stud 2000;38:275-90.

[14] UNESCO. Wise practises for conflict prevention and resolution in small islands. Results of a workshop on 'Furthering coastal stewardship in small islands', Dominica, 4-6 July 2001. Coastal region and small island papers 11. Paris: UNESCO; 2002. 70 p.

[15] State of the Environment Australia. DEST. Collingwood, Vic: CSIRO Publishing; 1996.

[16] King CJ. The first fifty years of agriculture in New South Wales. Rev Market Agric Econ Sydney 1948;16:362-86.

[17] White I, Melville MD, Wilson BP, Sammut J. Reducing acid discharge from estuarine wetlands in eastern Australia. Wetlands Ecol Manage 1997;5:55-72.

[18] Lin C, Melville MD. Control of soil acidification by fluvial sedimentation in an estuarine floodplain, eastern Australia. Sediment Geol 1993; $85: 1-13$.

[19] Sammut J, White I, Melville MD. Acidification of an estuary due to drainage from acid sulfate soils. Mar Freshwat Res 1996;4:669-84.

[20] Healthy Rivers Commission. Securing healthy coastal rivers: a strategic perspective. Sydney: Healthy Rivers Commission of New South Wales; 2000.

[21] Healthy Rivers Commission. Independent inquiry into coastal lakes. Final report, April 2002. Sydney: Healthy Rivers Commission of New South Wales; 2002. p. 74.

[22] Dent DL. Acid sulphate soils: a baseline for research and development, I.RI Pub. No. 39. Wageningen: International Institute for Land Reclamation and Improvement; 1986.

[23] Bush RT, McGrath R, Sullivan LA. Occurrence of marcasite in an organic-rich Holocene estuarine mud. Aust J Soil Res 2005;42:617-21.

[24] Brinkman R. Social and economic aspects of reclamation of acid sulphate soil areas. In: Dost H, van Breemen N, editors. Proc. Bangkok symposium on acid sulphate soils, 8-24 Jan 1981. ILRI Pub. No. 31. Wageningen: International Institute for Land Reclamation and Improvement; 1982. pp. 21-36.

[25] White I, Melville MD, Sammut J, Wilson BP, Bowman GM. Downstream impacts from acid sulfate soils. In: Hunter H, Eyles A, Rayment G, editors. Downstream impacts of land use. Brisbane: Department of Natural Resources; 1996. p. 165-72.

[26] Easton C. The trouble with the Tweed. Fishing World March; 1989. p. 58-9.

[27] Callinan RB, Fraser GC, Melville MD. Seasonally recurrent fish mortalities and ulcerative disease outbreaks associated with acid sulfate soils in Australian estuaries. In: Dent DL, van Mensvoort MEF, editors. Selected papers from the Ho Chi Minh City symposium on acid sulphate soils, Mar 1992. ILRI Pub. No. 53. Wageningen: International Institute for Land Reclamation and Improvement; 1993. pp. 403-10.

[28] Sammut J, Melville MD, Callinan RD, Fraser GC. Estuarine acidification: impacts on aquatic biota of draining acid sulphate soils. Aust Geog Stud 1995;33:89-100.

[29] Dennison WC, O’Neil JM, Duffy E, Oliver P, Shaw G. Blooms of the cyanobacterium Lyngbia majuscula in coastal waters of Queensland. In: Charpy L, Larkum AWD, editors. Proceedings of the international symposium on marine cyanobacteria, Nov 1997. Paris: Institut Oceanographique; 1997.

[30] Macdonald BCT, Denmead OT, White I, Melville MD. Natural sulfur dioxide emissions from sulfuric soils. Atmos Environ 2004;38:1473-80.

[31] Brown TE, Morley AW, Sanderson NT, Tait RD. Report on a large fish kill resulting from natural acid water conditions in Australia. J Fish Biol 1983;22:333-50.

[32] Noller BN, Cusbert PJ. Mobilization of aluminium from a tropical floodplain and its role in natural fish kills: a conceptual model. In: Lekkas TD, editor. Proceedings of the 5th conference on heavy metals in the environment, September 1985. Athens. Edinburgh: CEP Consultants Ltd; 1985. p. $700-2$.

[33] Hart BT, Ottoway EM, Noller BN. Magela Creek system, Northern Australia. I. 1982-83 wet season water quality. Aust J Mar Freshwat Res 1987;38:261-88.

[34] Simpson HJ, Pedini M. Brackish water aquaculture in the tropics: the problem of acid sulphate soils, FAO Fish Circ. No. 791. Rome: FAO; 1985.

[35] Macdonald BCT, Smith J, Keene AF, Tunks M, Kinsela A, White I. Impact of runoff from sulfuric soils on sediment chemistry in an estuarine lake. Sci Total Environ 2004;329:115-30.

[36] Nguyen Thanh Tin, Wilander A. Chemical conditions in acidic waters in the plain of reeds. Vietnam. Water Resour 1995;29:1401-8.

[37] Wilson BP, White I, Melville MD. Floodplain hydrology, acid discharge and water quality associated with a drained acid sulfate soil. Mar Freshwat Res 1999;50:149-57.

[38] Pons LJ. Outline of the genesis, characteristics, classification and improvement of acid sulphate soils. In: Dost H, editor. Proceedings of the international symposium on acid sulphate soils, 13-29 Aug 1972. ILRI Pub. No. 18, vol. 1. Wageningen: International Institute for Land Reclamation and Improvement; 1973. p. 3-27.

[39] Tuong TP. An overview of water management of acid sulphate soils. In: Dent DL, van Mensvoort MEF, editors. Selected papers from the Ho Chi Minh City symposium on acid sulphate soils, Mar 1992. ILRI Pub. No. 53. Wageningen: International Institute for Land Reclamation and Improvement; 1993. p. 265-79.

[40] Lin C, Melville MD. Acid sulphate soil-landscape relations in the Pearl River Dalta, Southern China. Catena 1994;22:105-20.

[41] Lin C, Melville MD, White I, Wilson BP. Human and natural controls on the accumulation, acidification and drainage of pyritic sediments: contrasts between the Pearl River Delta, China and coastal NSW. Aust Geog Stud 1995;33:77-88.

[42] Hamming AFJ, van den Eelaart ALJ. Soil permeability, interflow and actual acidity in acid sulfate soils, South Kalimantan, Indonesia. In: Dent DL, van Mensvoort MEF, editors. Selected papers from the Ho Chi Minh City symposium on acid sulphate soils, Mar 1992. ILRI Pub. No. 53. Wageningen: International Institute for Land Reclamation and Improvement; 1993. pp. 155-60.

[43] Kselik R, Smilde KW, Ritzema HP, Subagyono K, Saragih S, Damanik M, et al. Integrated research on water management, soil fertility and cropping systems on acid sulphate soils in South Kalimantan, Indonesia. In: Dent DL, van Mensvoort MEF, editors. Selected papers from the Ho Chi Minh City symposium on acid sulphate soils, Mar 1992. ILRI Pub. No. 53. Wageningen: International Institute for Land Reclamation and Improvement; 1993. pp. 177-94.

[44] Palko J, Yli-Halla M. Assessment and management of acidity released upon drainage of acid sulfate soils in Finland. In: Dent DL, van Mensvoort MEF, editors. Selected papers from the Ho Chi Minh City symposium on acid sulphate soils, Mar 1992. ILRI Pub. No. 53. Wageningen: International Institute for Land Reclamation and Improvement; 1993. pp. 411-8.

[45] Sundstrom RM, Astrom M, Osterholm P. Comparison of the metal content of acid sulphate soil runoff and industrial effluents in Finland. Environ Sci Technol 2002;36:4269-72.

[46] Portnoy JW. Salt marsh diking and restoration: biogeochemical implications of altered wetland hydrology. Environ Manage 1999;24:111-20.

[47] Woodward HP. Investigation into the cause of mineralisation of the "seven-mile" swamp at Grassmere, Southwest Division. WA Department of Mines Annual Report; 1917. pp. 49-57.

[48] Teakle LJH, Southern BL. The peat soils and related soils of Western Australia, II. A soil survey of Herdsman Lake. J Agric W A 1937;14: 404-24.

[49] Walker PH. Seasonal and stratigraphic controls in coastal floodplain soils. Aust J Soil Res 1972;10:127-42.

[50] Willett IR, Walker PH. Soil morphology and distribution of iron and sulphur fractions in a coastal flood plain toposequence. Aust J Soil Res 1982;20:283-94. 
[51] Naylor SD, Chapman GA, Atkinson G, Murphy CL, Tulau MJ, Flewin TC, et al. Guidelines for the use of acid sulphate soils risk maps. Sydney: NSW Soil Conservation Service, Dept. Land and Water Conservation; 1995.

[52] Melville MD, White I, Willett IR. Problems of acid sulphate soils and water degradation in Holocene pyritic systems, Proc workshop applied quaternary studies, 2-3 July 1990. Canberra: ANU; 1990. p. 89-95.

[53] Melville MD, White I, Lin C. The origins of acid sulphate soils. In: Proceedings of the national conference on acid sulphate soils, Coolangatta, 24-25 June 1993. Wollongbar: NSW Agriculture; 1993. pp. 19-25.

[54] White I, Melville MD. Treatment and containment of potential acid sulphate soils: formation, properties and management of potential acid sulphate soils. Report for Roads and Traffic Authority, NSW. Technical Report T53. CSIRO Centre for Environmental Mechanics; 1993.

[55] White I, Melville MD, Wilson BP, Price CB, Willett IR. Understanding acid sulphate soils in canelands. In: Proceedings of the national conference on acid sulphate soils, Coolangatta, 24-25 June 1993. Wollongbar: NSW Agriculture; 1993. pp. 130-48.

[56] Willett IR, Melville MD, White I. Acid drainwaters from potential acid sulphate soils and their impact on estuarine ecosystems. In: Dent DL, van Mensvoort MEF, editors. Selected papers from the Ho Chi Minh City symposium on acid sulphate soils, Mar 1992. ILRI Pub. No. 53. Wageningen: International Institute for Land Reclamation and Improvement; 1993. pp. 419-25.

[57] White I, Macdonald BCT, Melville MD. Modelling groundwater in soft, sulfidic, coastal sediments. In: Ghassemi F, Whetton P, Little R, Littleboy M, editors. Proceedings MODSIM, International Congress on Modelling and Simulation, Australian National University, Canberra, 10-13 December 2001. Natural systems (Part 2), vol 2. Modelling and Simulation Society of Australia and New Zealand, Inc; 2001. pp. 567-72.

[58] White I, Smiles DE, Santomartino S, van Oploo P, Macdonald BCT, Waite TD. Dewatering and the hydraulic properties of soft sulfidic soils. Water Resour Res 2003;39:1295. doi:10.1029/2002WR001324.
[59] Smith J, Marston H, Melville MD, Macdonald BCT. Spatial distribution and management of actual acidity in an acid sulfate soil environment, McLeods Creek, northeastern NSW, Australia. Catena 2003;51:61-79.

[60] Donner ENS, Melville MD. The effects of floodplain land use on the chemistry and hydrology of coastal acid sulfate soils. In: 5th International acid sulfate soils conference, Tweed Heads. Wollongbar, NSW: ASSMAC; 2002. pp. 1-2.

[61] Kinsela AS, Melville MD. Mechanisms of acid sulfate soil oxidation and leaching under sugarcane cropping. Aust J Soil Res 2004;42:569-78.

[62] Smith J, Melville MD. Iron monosulfide formation and oxidation in drain-bottom sediments of an acid sulfate soil environment. Appl Geochem 2004;19:1837-53.

[63] Woodhead A. Acid sulfate soils: farming community attitudes about the way forward. Wollongbar, NSW: NSW Agriculture and ASSMAC; 1999. p. 23.

[64] Woodhead A. Acid sulfate soils 4 years on - what changed? Wollongbar, NSW: NSW Agriculture and ASSMAC; 2003. p. 40.

[65] Beattie RN, Nielsen PJ, Rayment GE, Aitken RL, McGuire PJ, Quirk RJ. Achieving self-regulation for drain maintenance in the NSW sugar industry. Proc Aust Soc Sugar Cane Technol 2001;23:51-5.

[66] Williams J. Acid sulfate soils. In: OECD workshop on: An interdisciplinary dialogue: agricultural production and integrated ecosystem management of soil and water, Ballina, 10-16 Nov 2002. Sydney: OECD, Uni Western Sydney, NSW Agriculture; 2002. pp. 114-22.

[67] Blunden B, Naylor SD. Assessing and managing acid sulphate soils. Guidelines for land management in NSW coastal areas. Chatswood, NSW: NSW EPA 1995.

[68] Ashby J. Introduction: uniting science and participation in the process of innovation - research for development. In: Pound B, Snapp S, McDougall C, Braun A, editors. Managing natural resources for sustainable livelihoods: uniting science and participation. London: Earthscan Publications; 2003. 